\title{
Article \\ Quantitative Assessment of Natural Disaster Coping Capacity: An Application for Typhoons
}

\author{
Ting Wang ${ }^{1,2}$, Linsheng Yang ${ }^{1,2}\left(\mathbb{D}\right.$, Shaohong $\mathrm{Wu}^{1,2}{ }^{1}$, Jiangbo Gao ${ }^{1}(\mathbb{C})$ and Binggan Wei ${ }^{1, *(\mathbb{C})}$ \\ 1 Key Laboratory of Land Surface Pattern and Simulation, Institute of Geographic Sciences and Natural \\ Resources Research, Chinese Academy of Sciences, Beijing 100101, China; wangting.18s@igsnrr.ac.cn (T.W.); \\ yangls@igsnrr.ac.cn (L.Y.); wush@igsnrr.ac.cn (S.W.); gaojiangbo@igsnrr.ac.cn (J.G.) \\ 2 College of Resources and Environment, University of Chinese Academy of Sciences, Beijing 100049, China \\ * Correspondence: weibg@igsnrr.ac.cn; Tel.: +86-(0)10-6485-6504
}

Received: 17 June 2020; Accepted: 20 July 2020; Published: 23 July 2020

\begin{abstract}
At present, natural disaster coping capabilities are quantitively represented as high, moderate, or low. These classifications, which are described as the results of relative grades, have failed to reveal the specific grades of disaster coping capacity. Therefore, an assessment method of natural disaster coping capacity, which is attempted to quantify the natural disaster coping capacity as disaster grades, was proposed in this study. First, an indicator system consisting of disaster reduction ability index, disaster resilience ability index, and disaster relief ability index was established. The index values were defined as disaster grades according to the historical disaster-related data and information on the equipment and infrastructure for disaster prevention. Second, the weights assigned to these indicators were assessed by using the analytic hierarchy process (AHP). Then, the back propagation (BP) neural network was used to examine the indicator weights. Finally, the disaster coping capacity was estimated by using the fuzzy comprehensive evaluation model. The assessment result was characterized as disaster grade. Cangnan county was chosen as a case study for the assessment of typhoon coping capacity by the proposed method. The results showed that the coping capacity of the county was prepared to deal with 12-13 intensity grades of typhoon. The assessment carried out using the proposed method accurately reflected the typhoon coping capacity of Cangnan. Moreover, the index values of disaster reduction ability, disaster resilience, and disaster relief ability revealed the advantages and limitations of typhoon coping capacity. This suggests that natural disaster coping capacity can be quantitatively assessed by the proposed method.
\end{abstract}

Keywords: natural disaster; coping capacity; AHP-BP neural network; fuzzy comprehensive evaluation; quantitative estimation

\section{Introduction}

Natural disasters pose daunting challenges for humans. The scale and frequency of natural disasters have exhibited a rising trend in the 21st century due to the impact of climate change [1-5]. They usually induce great loss of life and property worldwide. From 1998 to 2017, natural disasters induced 1.3 million population deaths and caused 2908 billion dollars of loss [6]. China was widely affected by various types of natural disasters [7,8]. In 2019, a total of 130 million people were affected and 909 people died from natural disasters in China. In addition, more than 40 billion dollars were lost [9]. The loss caused by natural disasters was usually associated with the disaster grade. The natural disaster coping capacity also played an important role in the loss from disaster [10,11]. Therefore, the mitigation of disaster risk obtained increasing attention [12]. Natural disaster coping capacity has 
emerged as an area of intensive research in recent years [2,13-15]. Since 2016, the Chinese government has also begun focusing on improving the country's natural disaster coping capacity.

Natural disaster coping capacity reflects the ability of people, organizations, and systems, using available skills and resources, to manage adverse conditions, risk, or disasters, where capacity includes infrastructure, institutions, human knowledge and skills, and collective attributes such as social relationships, leadership, and management [16]. Disaster coping capacity was rarely a concern of international organizations or countries until the Guidelines for Natural Disaster Prevention, Preparedness, and Mitigation were released in 1994 [17]. The guidelines induced wide and long-term impacts on natural disaster coping capacity assessment [18]. In 1997, the United States originally issued the State and Local Government Capability Assessment for Readiness (CAR) [19]. Furthermore, every state of the USA has proposed criteria for the assessment of disaster coping capacity. The assessment index system includes communication, disaster warning, training, financial management, etc. [20]. In 2001, Australia assessed natural disaster management capacity based on policy, preparedness measures, disaster reduction measures, and post-disaster assessment [21]. Japan estimated natural disaster coping capacity according to emergency response, post-disaster reconstruction, training, etc. [20]. In China, studies about the assessment of natural disaster coping capacity have been conducted since $2000[22,23]$.

The estimation of natural disaster coping capacity is the basis for formulating plans and improvement. It is an important area of research in the geographical sciences [10,24-28]. The indicators used in current index systems to estimate natural disaster coping capacity in China usually include casualties, economic losses, restoration, disaster prevention, and disaster preparedness [29-34]. Some researchers suggested that natural disaster coping capacity included disaster prevention, disaster relief, and disaster recovery $[20,35]$. Several studies used casualties, economic losses, and recovery time to estimate disaster coping capacity [23]. However, these index systems vary significantly in terms of the content and indicators, and no systematic and uniform indicator system is available to estimate natural disaster coping capacity [36-39]. The assessment methods of disaster coping capacity mainly include coping index, fuzzy comprehensive evaluation, and the back propagation (BP) neutral network [40-43]. However, the estimation results using these methods are mainly characterized as scores or relative rank values. The disaster coping capacity is classified as high, moderate, or low. These classifications have failed to reveal whether a region's available natural disaster coping capacity is adequate to deal with a specific natural disaster grade. In addition, it is difficult to identify the factors limiting the coping capacity.

Therefore, it is important to establish a quantitative method that can determine disaster coping capacity for different disaster grades. The assessment results can be used to identify the advantages and disadvantages of disaster coping capacity, and can provide planning and decision support for disaster management. Therefore, this study developed an index system, including disaster reduction ability index, disaster resilience ability index, and disaster relief ability index, for the assessment of natural disaster coping capacity based on historical disaster-related data and information on the available equipment and infrastructure for disaster reduction. The analytic hierarchy process (AHP) and the back propagation (BP) neural network were used to estimate and verify the weights of indicators. A fuzzy comprehensive evaluation model was applied to assess natural disaster coping capacity, which was expressed according to the corresponding disaster grade. A case study was conducted to verify the feasibility of the proposed method and the reliability of the estimation results. The work here can provide a scientific basis for assessing natural disaster coping capacity at the regional scale.

\section{Materials and Methods}

\subsection{Conceptualization of Assessment Framework}

The concept of the quantitative assessment of natural disaster coping capacity is depicted in Figure 1. 


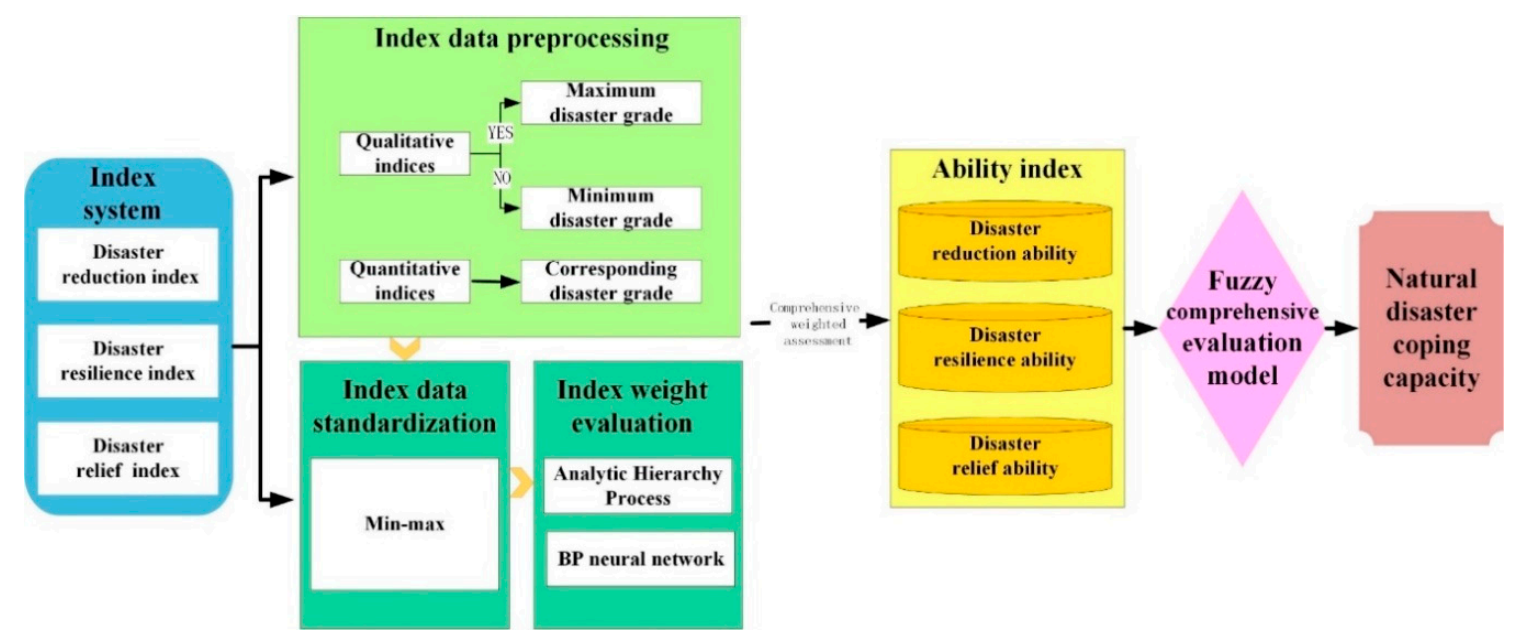

Figure 1. Conceptual approach to quantitative assessment of natural disaster coping capacity.

First, an index system of natural disaster coping capacity, which includes disaster reduction ability index, disaster resilience ability index, and disaster relief ability index, was established. Second, data for the indices were collected and preprocessed. To quantify the index data as disaster grade, the indices were divided into qualitative and quantitative indices. The qualitative indices included equipment for disaster monitoring and disaster warning. We used descriptive words such as "Yes'" and "No." "Yes" describes "the highest disaster grade given the disaster monitor equipment in a given region, whereas "No" signifies the lowest disaster grade where the requisite equipment is lacking. The quantitative indices included the disaster-fighting grade of a house and other facilities. The data were calculated by using historical data and infrastructure-related information. For instance, the refuge coping grade was determined through the relationship between refuge capacity and the number of people who required emergency transfer associated with the historical disaster grade. Third, in order to ensure full comparability among different indices, all the index data of natural disaster coping capacity were standardized. Fourth, the AHP-BP neural network was used to determine the weight of each index. Finally, the index values of disaster reduction ability, disaster resilience ability, and disaster relief ability were estimated by an index-weighted assessment according to the data. The fuzzy comprehensive evaluation model was then used to assess natural disaster coping capacity. The fuzzy comprehensive evaluation model is considered a multi-factor system with fuzzy characteristics. The fuzzy set can be used to describe the disaster coping capacity in case of many factors.

\subsection{Index System}

Natural disaster coping capacity assessment included monitoring, forecasting, early warning, insurance, and other measures. At present, most of the index systems for evaluation of natural disaster coping capacity had some deficiencies. The time series of natural disasters (pre-disaster, in-disaster, and post-disaster), the literature [34,44] and the principle of index selection, variety factors of disaster coping capacity, and opinions of various experts were considered for the index system in this paper. Therefore, the index system for typhoon coping capacity is described as a function of three dimensions, namely reduction ability, resilience ability, relief ability. The index system contained 21 secondary indices (Table 1). 
Table 1. Index system for typhoon coping capacity.

\begin{tabular}{|c|c|c|c|}
\hline Target Layer & First-Grade Index & Second-Grade Index & Description \\
\hline \multirow{21}{*}{ Typhoon coping capacity } & \multirow{8}{*}{ Typhoon reduction ability } & Monitoring time resolution & $\begin{array}{l}\text { The monitoring equipment operates in real time } \\
\text { (Yes/No) }\end{array}$ \\
\hline & & Monitoring stations & Number of disaster monitoring stations $\geq 1$ (Yes/No) \\
\hline & & Warning systems & Number of disaster warning systems $\geq 1$ (Yes/No) \\
\hline & & Warning time resolution & $\begin{array}{l}\text { The warning system issues early warning } \\
\text { information in real time (Yes/No) }\end{array}$ \\
\hline & & $\begin{array}{l}\text { Typhoon coping grade of housing } \\
\text { insurance }\end{array}$ & $\begin{array}{l}\text { The ratio of purchasing natural disaster farm house } \\
\text { insurance is higher than that of farm house collapse } \\
\text { caused by the specific typhoon grade (grade) }\end{array}$ \\
\hline & & $\begin{array}{l}\text { Typhoon coping grade of public } \\
\text { awareness }\end{array}$ & $\begin{array}{l}\text { The highest typhoon grade encountered by } \\
\text { the public (grade) }\end{array}$ \\
\hline & & Typhoon coping grade of hospital & $\begin{array}{c}\text { The number of hospital beds is sufficient to deal with } \\
\text { people injured by a typhoon of a specific } \\
\text { grade (grade) }\end{array}$ \\
\hline & & Disaster research institute & $\begin{array}{c}\text { Number of disaster scientific research institutes } \geq 1 \\
(\text { Yes/No) }\end{array}$ \\
\hline & \multirow{8}{*}{ Typhoon resilience ability } & $\begin{array}{l}\text { Flood control grade of flood } \\
\text { control projects }\end{array}$ & $\begin{array}{l}\text { Flood control standard of flood control } \\
\text { projects (grade) }\end{array}$ \\
\hline & & $\begin{array}{l}\text { Flood control grade of traffic } \\
\text { facilities }\end{array}$ & Flood control standard of traffic facilities (grade) \\
\hline & & $\begin{array}{l}\text { Flood control grade of } \\
\text { communication facilities }\end{array}$ & $\begin{array}{l}\text { Flood control standard of communication } \\
\text { facilities (grade) }\end{array}$ \\
\hline & & $\begin{array}{l}\text { Flood control grade of power } \\
\text { facilities }\end{array}$ & Flood control standard of power facilities (grade) \\
\hline & & Anti-wind grade of house & Anti-wind standard of house (grade) \\
\hline & & Anti-wind grade of traffic facilities & Anti-wind standard of traffic facilities (grade) \\
\hline & & $\begin{array}{l}\text { Anti-wind grade of } \\
\text { communication facilities }\end{array}$ & $\begin{array}{l}\text { Anti-wind standard of communication } \\
\text { facilities (grade) }\end{array}$ \\
\hline & & $\begin{array}{l}\text { Anti-wind grade of power } \\
\text { facilities }\end{array}$ & Anti-wind standard of power facilities (grade) \\
\hline & \multirow{5}{*}{ Typhoon relief ability } & Typhoon emergency response plan & $\begin{array}{c}\text { The number of government emergency plans for } \\
\text { typhoon }>3 \text { (Yes/No) }\end{array}$ \\
\hline & & $\begin{array}{l}\text { Typhoon coping grade of relief } \\
\text { materials }\end{array}$ & $\begin{array}{l}\text { Relief materials are sufficient to cope with } \\
\text { the typhoon grade (grade) }\end{array}$ \\
\hline & & Typhoon coping grade of refuges & $\begin{array}{l}\text { Refuges can cope with emergency transfer due to } \\
\text { the typhoon of the given grade (grade) }\end{array}$ \\
\hline & & $\begin{array}{l}\text { Typhoon coping grade of } \\
\text { fire-fighting equipment }\end{array}$ & $\begin{array}{l}\text { The fire equipment is adequate to deal with } \\
\text { the typhoon grade (grade) }\end{array}$ \\
\hline & & $\begin{array}{l}\text { Typhoon coping grade of } \\
\text { emergency equipment }\end{array}$ & $\begin{array}{l}\text { Emergency equipment can deal with the typhoon } \\
\text { grade at hazardous sites (grade) }\end{array}$ \\
\hline
\end{tabular}

(1) The index for typhoon reduction ability included the monitoring time resolution, monitoring stations, warning systems, warning time resolution, typhoon coping grade of housing insurance, grade of public awareness, typhoon coping grade of the hospital, and the disaster research institute. The monitoring ability was the basis for the capabilities of natural disaster prevention and rescue operations, and played an important role in early warning. The warning platform for natural disasters was an important pathway for the public to learn about natural disasters. The popularization of education related to disaster prevention and mitigation can reduce the loss of life and property. Public awareness, disaster science and technology, insurance, medicine, and others also played an important role in disaster prevention. (2) The index for typhoon resilience ability consisted of the flood control grade or anti-wind grade of power facilities, communications facilities, traffic facilities, anti-wind grade of house, and the flood control grade of flood control projects. The anti-wind grade of house, which directly affected the safety of the residents, was the most immediate anti-wind infrastructure available to the public. The anti-wind or flood control grade of public facilities, such as transportation, communication, and power infrastructures, reflected the development level of disaster coping capacity. (3) The index for typhoon relief ability referred to the supply of relief materials, equipment, and the availability of a typhoon emergency response plan.

According to the quantitative characteristics of the data, the indices were divided into qualitative and quantitative indices. The qualitative index included the disaster monitoring station and monitoring 
time resolution, warning time resolution, and typhoon emergency response plan, etc. The quantitative index covered the typhoon coping grade of hospital and anti-wind grade of house, etc.

\subsection{Preprocessing Index Data}

The assessment of typhoon coping capacity was chosen to illustrate the preprocessing of the index data, including data cleaning and conversion. Data cleaning was mainly to delete the typhoon events data which slightly influenced the study area, also to correct the mistake or biased disaster data. Data conversion involved converting equipment- and infrastructure-related information into disaster grades by using historical disaster-related data.

(1) Qualitative index

The qualitative indices were converted as follows:

$$
X=\left\{\begin{array}{c}
7, Y<1, \text { or "no" } \\
17, Y \geq 1, \text { or "yes" }
\end{array}\right.
$$

$X$ represents the preprocessed values of the qualitative indicators, $Y$ represents the monitoring stations, warning system, warning time resolution, typhoon emergency response plan, or monitoring time resolution.

\section{(2) Quantitative index}

The quantitative indices referred to values characterized by typhoon grade using mathematical operations based on historical typhoon-related data. Table 2 shows methods for quantitative index data conversion.

Table 2. Data conversion of quantitative index for typhoon coping capacity.

\begin{tabular}{|c|c|}
\hline Index & Conversion \\
\hline Typhoon coping grade of housing insurance & $\begin{array}{l}\text { The proportion of purchased natural disaster house insurance } \\
(Y) \text { corresponding to the typhoon grade }(X) \text { determined by the } \\
\text { curve between historical typhoon grade }\left(X_{k}\right) \text { and house } \\
\text { collapse }\left(Y_{k}\right) \text {. }\end{array}$ \\
\hline Typhoon coping grade of public awareness & The highest typhoon grade encountered by the public (grade). \\
\hline Typhoon coping grade of hospital & $\begin{array}{l}\text { The number of hospital beds }(Y) \text { corresponding to the typhoon } \\
\text { grade }(X) \text { determined by the curve between the historical } \\
\text { typhoon grade }\left(X_{k}\right) \text { and the injured population }\left(Y_{k}\right) \text {. }\end{array}$ \\
\hline Flood control grade of flood control projects & $\begin{array}{l}\text { The minimum daily cumulative rainfall }(Y) \text { in case of flood } \\
\text { corresponding to the typhoon grade }(X) \text { determined by the } \\
\text { curve between historical typhoon grade }\left(X_{k}\right) \text { and daily } \\
\text { cumulative rainfall }\left(Y_{k}\right) \text {. }\end{array}$ \\
\hline Flood control grade of traffic facilities & $\begin{array}{l}\text { The designed daily cumulative rainfall that transportation } \\
\text { facilities can handle }(Y) \text { to the corresponding typhoon grade } \\
(X) \text { determined by the curve between historical typhoon grade } \\
\left(X_{k}\right) \text { and maximum daily cumulative rainfall }\left(Y_{k}\right) \text {. }\end{array}$ \\
\hline Flood control grade of communication facilities & $\begin{array}{l}\text { The designed daily cumulative rainfall that communication } \\
\text { facilities can handle }(Y) \text { to the corresponding typhoon grade } \\
(X) \text { determined by the curve between the historical typhoon } \\
\text { grade }\left(X_{k}\right) \text { and the maximum daily cumulative rainfall }\left(Y_{k}\right) \text {. }\end{array}$ \\
\hline Flood control grade of power facilities & $\begin{array}{l}\text { The designed daily cumulative rainfall that power facilities can } \\
\text { handle }(Y) \text { to the corresponding typhoon grade }(X) \text { determined } \\
\text { by the curve between the historical typhoon grade }\left(X_{k}\right) \text { and the } \\
\text { maximum daily cumulative rainfall }\left(Y_{k}\right) \text {. }\end{array}$ \\
\hline Anti-wind grade of house & $\begin{array}{l}\text { The anti-wind grade of house as determined by the stress level, } \\
\text { structure, and other indices. }\end{array}$ \\
\hline
\end{tabular}


Table 2. Cont.

\begin{tabular}{cl}
\hline \multicolumn{1}{c}{ Index } & \multicolumn{1}{c}{ Conversion } \\
\hline Anti-wind grade of power facilities & $\begin{array}{l}\text { The maximum wind speed that power facilities can handle }(Y) \\
\text { to the corresponding typhoon grade }(X) \text { determined by the } \\
\text { curve between the typhoon grade }\left(X_{k}\right) \text { and the maximum wind } \\
\text { speed }\left(Y_{k}\right) .\end{array}$ \\
\hline Anti-wind grade of communication facilities & $\begin{array}{l}\text { The maximum wind speed that communication facilities can } \\
\text { handle }(Y) \text { to the corresponding typhoon grade }(X) \text { determined } \\
\text { by the curve between the typhoon grade }\left(X_{k}\right) \text { and the } \\
\text { maximum wind speed }\left(Y_{k}\right) \text {. }\end{array}$ \\
\hline Typhoon coping grade of relief material & $\begin{array}{l}\text { The number of items of equipment }(Y) \text { corresponding to the } \\
\text { typhoon grade }(X) \text { determined by the curve between the } \\
\text { typhoon grade }\left(X_{k}\right) \text { and demand for the material from victims } \\
\text { of disaster }\left(Y_{k}\right) \text {. }\end{array}$ \\
\hline Typhoon coping grade of refuges & $\begin{array}{l}\text { The refuge capacity }(Y) \text { corresponding to the typhoon grade } \\
(X) \text { determined by the curve between the typhoon grade }\left(X_{k}\right) \\
\text { and victims of the disaster }\left(Y_{k}\right) .\end{array}$ \\
\hline
\end{tabular}

\subsection{Standardizing Index Data}

The magnitudes and units of the index data varied widely. They were standardized by using the min-max standardization method.

In general, the typhoons of 7-17 intensity grades can land in residential areas. We assumed that the corresponding value for a typhoon of intensity grade 17 was 1 , and that one of intensity grade 7 was 0 . The index data were standardized as follows:

$$
Y_{i}=\frac{X_{i}-X_{\min }}{X_{\max }-X_{\min }}
$$

where $Y_{i}$ is the standardized value, $X_{i}$ is the value of the pre-processed typhoon coping index data, $i=1$, $2,3,4, \ldots, n$, and "min" and "max" are the minimum and maximum values of each index, respectively.

\subsection{Index Weight Determination}

The analytic hierarchy process (AHP), as a multi-objective decision-making method, obtained the quantitative analysis of indices according to the subjective judgment of experts. The method included hierarchical framework establishing, judgment matrixes constructing, index weight calculating, and consistency testing. The BP neural network, composed of the input layer, hidden layer, and output layer, was a multi-network training with index weights by nonlinear differential function. It was widely used to reduce the influence of human subjective factors. Therefore, the index weight for typhoon coping capacity was calculated and verified by the AHP-BP neural network. Firstly, the index weight was calculated by AHP. Secondly, the index values of disaster reduction ability, disaster resilience ability, and disaster relief ability were calculated according to the index weight and the index values. Finally, the index values of 17 towns obtained in the previous step were randomly selected for training the BP neural network model. The index values for the other 2 towns were verified by the values from the BP neural network. The error values must be lower than 0.1 .

\subsection{Quantitative Assessment Model}

The disaster coping capacity is represented by a fuzzy system that considered the society, economy, population, and the environment. All these factors can significantly affect the estimation results of disaster coping capacity. Fuzzy comprehensive evaluation is usually applied to deal with fuzzy systems [28,32]. Typhoon coping capacity was assessed by using the fuzzy comprehensive evaluation method. 
(1) Coping capacity factor set $U=\left[U_{1}, U_{2}, U_{3}\right]$. They were calculated as follows:

$$
\begin{gathered}
U_{1}=W_{P 1} \times Y_{P 1}+W_{P 2} \times Y_{P 2}+\cdots+W_{P 7} \times Y_{P 7} \\
U_{2}=W_{R 1} \times Y_{R 1}+W_{R 2} \times Y_{R 2}+\cdots+W_{R 7} \times Y_{R 7} \\
U_{3}=W_{M 1} \times Y_{M 1}+W_{M 2} \times Y_{M 2}+W_{M 3} \times Y_{M 3}
\end{gathered}
$$

where $U_{1}$ is the reduction ability factor set, $U_{2}$ is the resilience ability factor set, and $U_{3}$ is the relief ability factor set. $Y_{P}, Y_{R}$ and $Y_{M}$ represent the normalized values of the indices for reduction ability, resilience ability, and relief ability. $W_{P}, W_{R}$, and $W_{M}$ refer to the index weights reduction ability, resilience ability, and relief ability, respectively.

(2) Evaluation set $(V)$. Index values of the disaster coping capacity were divided into 10 intensity grades according to the typhoon grade $V=\left[V_{1}, V_{2}, V_{3}, V_{4}, V_{5}, V_{6}, V_{7}, V_{8}, V_{9}, V_{10}\right]$, where $V_{1}, V_{2}, \ldots$, $V_{10}$ indicated the typhoon grade corresponding to " 8 ", " 9 ", " $10 ", \ldots$, and " 17 ".

(3) Evaluation matrix $(R)$. The evaluation matrix is corresponding to the membership degrees of indices in the evaluation set. This degree is determined by a membership degree function $\left(U_{i j}\right)$. The triangle membership function is used to determine the membership degree. Namely, the membership degree of any normalized index value at the corresponding disaster grade was determined by a combination of the membership functions of the large and small triangles [32].

The formula for $V_{i}$ is listed as follows:

$$
U_{i j}=\left\{\begin{array}{c}
1, x=D_{j} \\
\frac{x-D_{j}}{D_{j+1}-D_{j}}, D_{j}<x<\frac{D_{j}+D_{j+1}}{2}
\end{array}\right.
$$

where $U_{i j}$ is the membership degree of index $i$ in grade $j(i=1,2,3 ; j=1,2,3, \ldots, 10)$, and $x$ represents the normalized index data.

The formula for $V_{(i+1)}$ is as follows:

$$
U_{i j+1}=\left\{\begin{array}{c}
\frac{D_{j+1}-x}{D_{j+1}-D_{j}}, \frac{D_{j}+D_{j+1}}{2} \leq x<D_{j+1} \\
1, x=D_{j+1}
\end{array}\right.
$$

where $U_{i j}$ and $U_{(i j+1)}$ indicate the membership degrees of the capabilities for typhoon reduction, typhoon resilience, or typhoon relief. $D_{j}$ and $D_{(j+1)}$ indicate grades of typhoon coping capacity corresponding to the index value. The relationship between the grade of typhoon coping capacity and the index value is listed in Table 3.

Table 3. The relationship between the grade of typhoon coping capacity and the index value.

\begin{tabular}{ccccccccccc}
\hline & \multicolumn{10}{c}{ Grade } \\
\cline { 2 - 11 } Indicators & $\boldsymbol{D}_{1}$ & $\boldsymbol{D}_{2}$ & $\boldsymbol{D}_{3}$ & $\boldsymbol{D}_{4}$ & $\boldsymbol{D}_{5}$ & $\boldsymbol{D}_{6}$ & $\boldsymbol{D}_{7}$ & $\boldsymbol{D}_{8}$ & $\boldsymbol{D}_{9}$ & $\boldsymbol{D}_{10}$ \\
\cline { 2 - 12 } & $\mathbf{8}$ & $\mathbf{9}$ & $\mathbf{1 0}$ & $\mathbf{1 1}$ & $\mathbf{1 2}$ & $\mathbf{1 3}$ & $\mathbf{1 4}$ & $\mathbf{1 5}$ & $\mathbf{1 6}$ & $\mathbf{1 7}$ \\
\hline Typhoon reduction ability & 0.1 & 0.2 & 0.3 & 0.4 & 0.5 & 0.6 & 0.7 & 0.8 & 0.9 & 1 \\
Typhoon resilience ability & 0.1 & 0.2 & 0.3 & 0.4 & 0.5 & 0.6 & 0.7 & 0.8 & 0.9 & 1 \\
Typhoon relief ability & 0.1 & 0.2 & 0.3 & 0.4 & 0.5 & 0.6 & 0.7 & 0.8 & 0.9 & 1 \\
\hline
\end{tabular}

The evaluation matrix $(R)$ was represented as:

$$
R=\left[\begin{array}{llll}
u_{1,1} & u_{1,2} & \cdots & u_{1,10} \\
u_{2,1} & u_{2,2} & \cdots & u_{2,10} \\
u_{3,1} & u_{3,2} & \cdots & u_{3,10}
\end{array}\right]
$$


(4) The evaluation results of typhoon coping capacity by the fuzzy comprehensive were calculated as:

$$
B=A \times R
$$

where $B$ represents the fuzzy comprehensive evaluation results of typhoon coping capacity, $A$ represents the matrix of index weights, and $\mathrm{R}$ represented the evaluation matrix, the value in the matrixes $(A, B$, or $R$ ) is between 0 and 1 .

(5) The grade of the typhoon coping capacity $P$ was calculated as follow:

$$
P=B V^{T}
$$

where $T$ refers to the matrix transposition, $V=\left[\begin{array}{l}8 \\ 9\end{array} 10111213141516\right.$ 17]. The value of $P$ represents the grade of typhoon coping capacity $(7<P \leq 17)$.

\section{Evaluation Case}

\subsection{Area for Case Study}

Cangnan County is located in the coastal area of Zhejiang Province. It covers an area of $1261 \mathrm{~km}^{2}$ with a 155-km-long coastline. It includes 19 towns (Figure 2) and has a population of 1.184 million. Cangnan County has a mid-subtropical monsoon climate, with significant alternation between winter and summer, distinct seasons, and a mild climate. Typhoons accompanied by heavy rain occurred frequently. In 2000-2016, a total of 25 to 35 times a typhoon occurred in Cangnan county, including Saomai, Sepat, Fitow, Soudelor, etc. According to the historical data, the rainfall of typhoons in this region was characterized by high intensity and concentrated, especially during powerful typhoons. This usually induced heavy flooding, serious damage to infrastructure, agriculture, forestry, and fisheries losses. The Saomai Typhoon in 2006 caused 73,000 houses to collapse and induced a loss of 9.1 billion RMB.

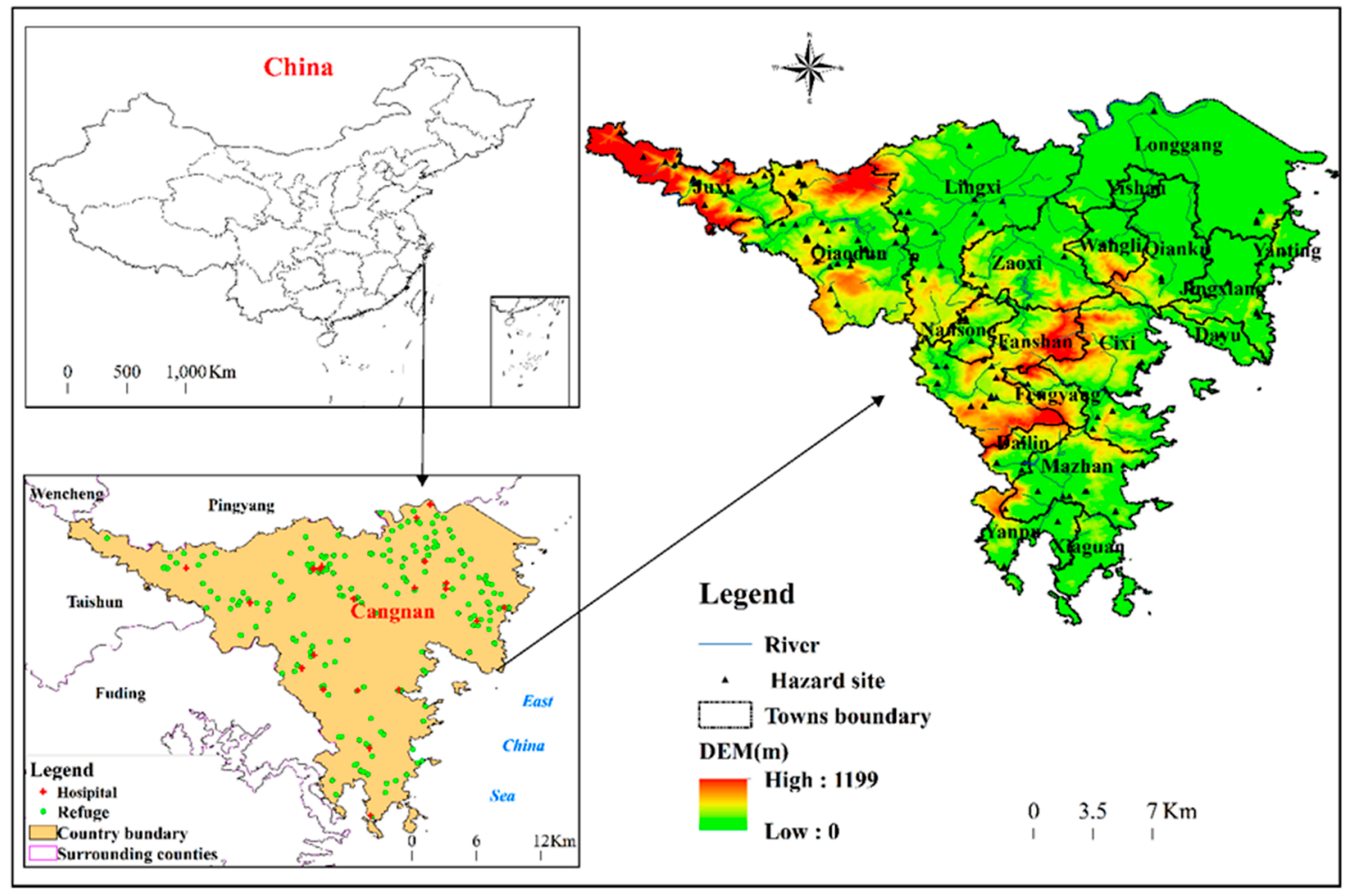

Figure 2. Location of area for the case study. 


\subsection{Data Source}

The socioeconomic data used to assess typhoon coping capacity were obtained from the Wenzhou Statistical Yearbook (2001-2016). Such basic data as those pertaining to the water systems and anti-wind grades of houses were provided by the emergency department of Cangnan County, Zhejiang Province. Climate data were obtained from the China Meteorological Administration, and administrative division data were taken from the Geospatial Data Cloud database and the National Catalogue Service for geographic information systems.

\subsection{Results}

\subsubsection{Index Weight}

An index system for the typhoon coping capacity of Cangnan was established according to the index system of typhoon coping capacity in Table 1. Based on the availability of data for the index system, 17 indices were obtained for the assessment of typhoon coping capacity in Cangnan. The obtained indices covered the three domains of typhoon reduction ability, typhoon resilience ability, and typhoon relief ability (Table 4). Therefore, the 17 indices were reliable for the assessment of typhoon coping capacity. The AHP was then applied to calculate the weights of the 17 indices.

Table 4. Index weights for typhoon coping capacity in Cangnan County.

\begin{tabular}{|c|c|c|c|}
\hline Figure & Weight & Second-Grade Index & Weight \\
\hline \multirow{7}{*}{ Typhoon reduction ability } & \multirow{7}{*}{0.4429} & Monitoring time resolution & 0.0479 \\
\hline & & Monitoring stations & 0.0479 \\
\hline & & Warning systems & 0.0857 \\
\hline & & Warning time resolution & 0.0857 \\
\hline & & Typhoon coping grade of housing insurance & 0.0445 \\
\hline & & Typhoon coping grade of public awareness & 0.0774 \\
\hline & & Typhoon coping grade of hospital & 0.0538 \\
\hline \multirow{7}{*}{ Typhoon resilience ability } & \multirow{7}{*}{0.3873} & Flood control grade of flood control projects & 0.1321 \\
\hline & & Flood control grade of traffic facilities & 0.0283 \\
\hline & & Flood control grade of communication facilities & 0.0133 \\
\hline & & Flood control grade of power facilities & 0.0199 \\
\hline & & Anti-wind grade of house & 0.1291 \\
\hline & & Anti-wind grade of power facilities & 0.0323 \\
\hline & & Anti-wind grade of communication facilities & 0.0323 \\
\hline \multirow{3}{*}{ Typhoon relief ability } & \multirow{3}{*}{0.1688} & Typhoon emergency response plan & 0.053 \\
\hline & & Typhoon coping grade of relief materials & 0.0336 \\
\hline & & Typhoon coping grade of refuges & 0.0832 \\
\hline
\end{tabular}

Finally, the BP neural network was used to verify the accuracy of the results. The results of index weights are shown in Table 5.

Table 5. Results of comparison between the analytic hierarchy process (AHP) method and the back propagation (BP) neural network model.

\begin{tabular}{ccccc}
\hline \multirow{2}{*}{ Index } & \multirow{2}{*}{ Town } & \multicolumn{2}{c}{ The Evaluation Value from a Different Way } & \multirow{2}{*}{ Error } \\
\cline { 2 - 5 } & & Result of the AHP & Result of the BP Neural Network & 0.0308 \\
\hline \multirow{2}{*}{ Typhoon reduction ability } & Mazhan & 0.8705 & 0.8437 & 0.0014 \\
\cline { 2 - 5 } & Longgang & 0.8110 & 0.8122 & 0 \\
\hline \multirow{2}{*}{ Typhoon resilience ability } & Lingxi & 0.4243 & 0.4243 & -0.0001 \\
\cline { 2 - 5 } & Nansong & 0.3802 & 0.3803 & 0.0001 \\
\hline \multirow{2}{*}{ Typhoon relief ability } & Zaoxi & 0.5279 & 0.5278 & 0.0001 \\
\cline { 2 - 5 } & Qianku & 0.3853 & 0.3852 & 0 \\
\hline
\end{tabular}




\subsubsection{Typhoon Coping Capacity}

(1) Typhoon reduction ability index

Index values of the typhoon reduction ability for each town in the county are shown in Figure 3a. The highest value (0.88) was recorded for Lingxi. The index values varied slightly among the towns. This might be attributed to equal values of the second-grade index, except for those of housing insurance (Figure 4a).
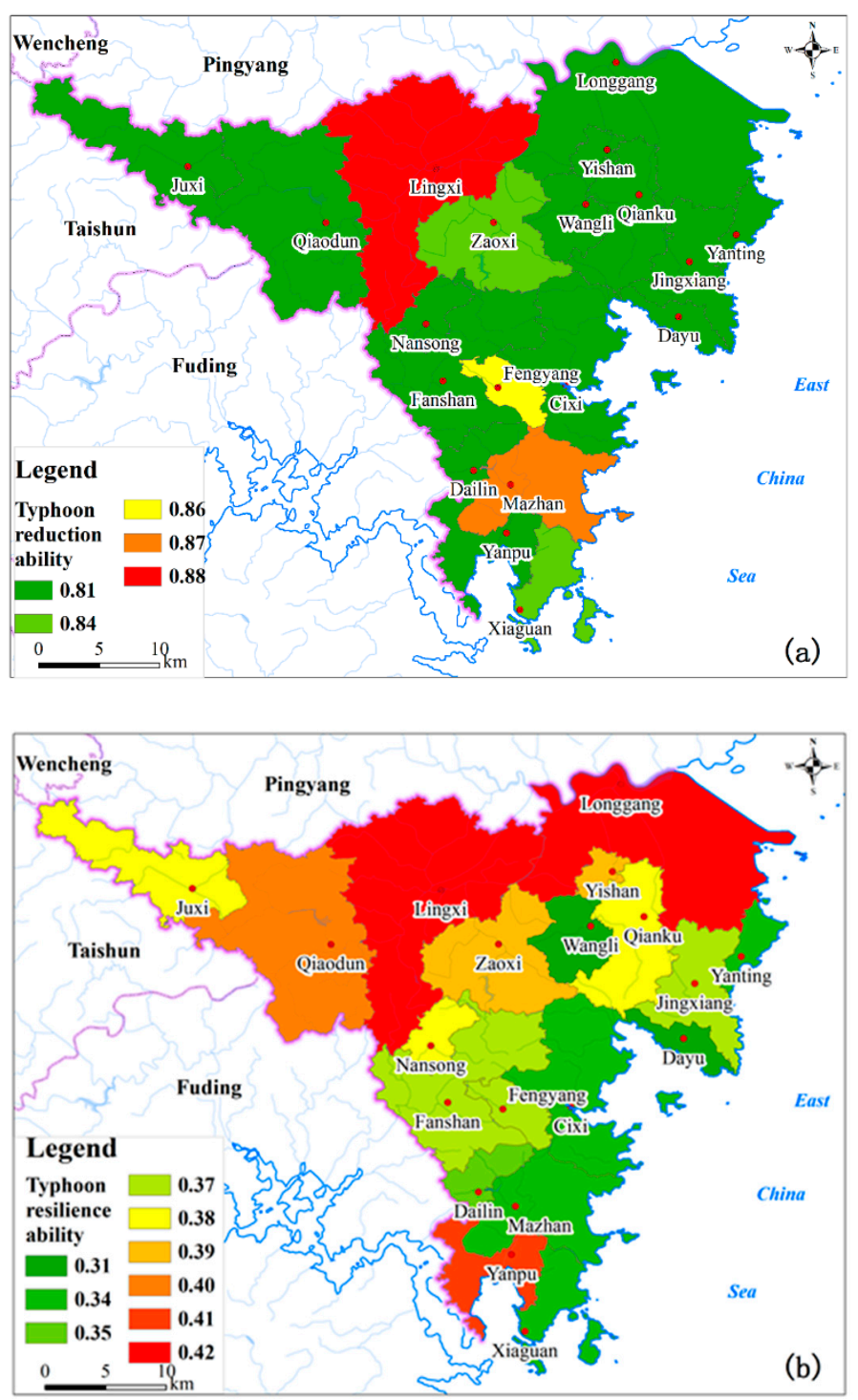

Figure 3. Cont. 


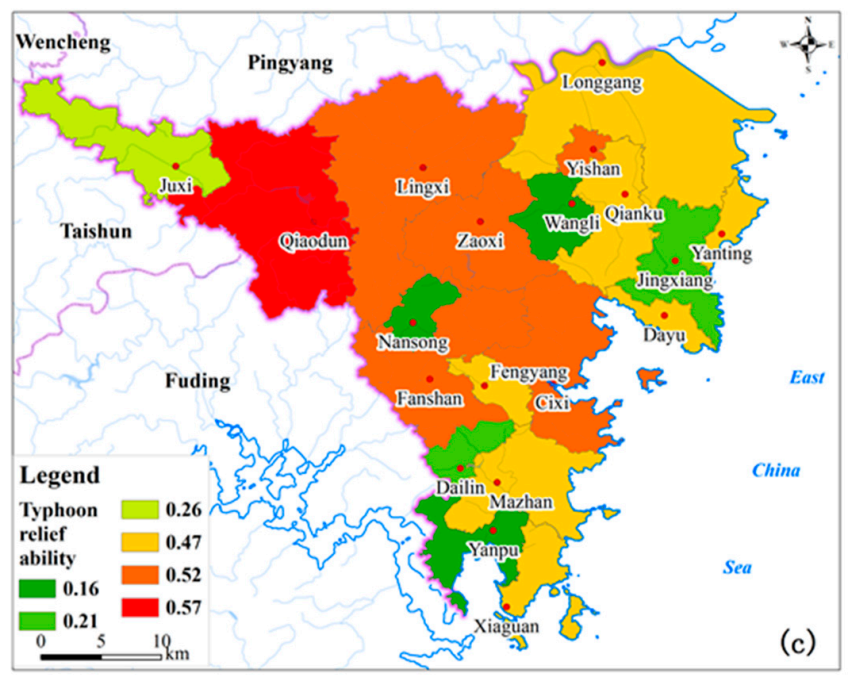

Figure 3. Spatial distribution of index values of typhoon reduction ability (a), resilience ability (b), and relief ability $(\mathbf{c})$.

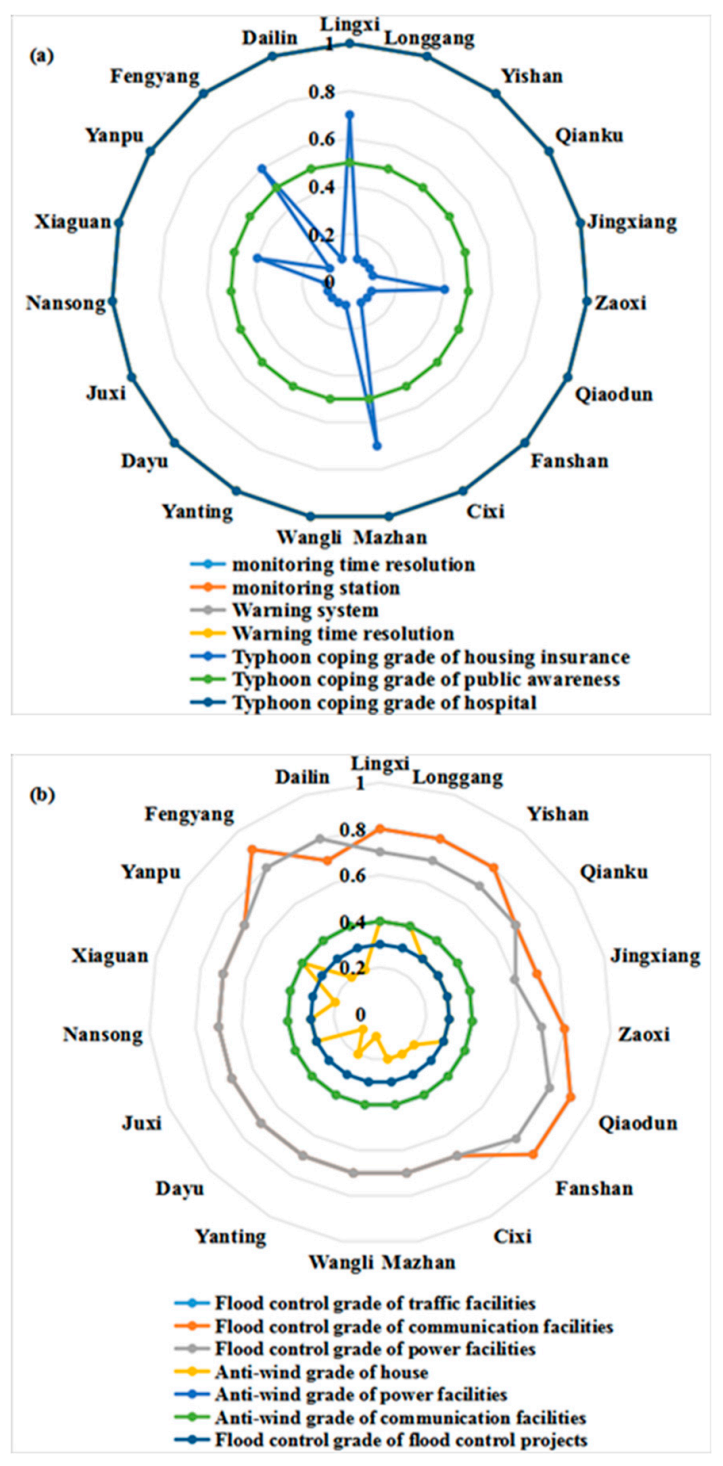

Figure 4. Cont. 


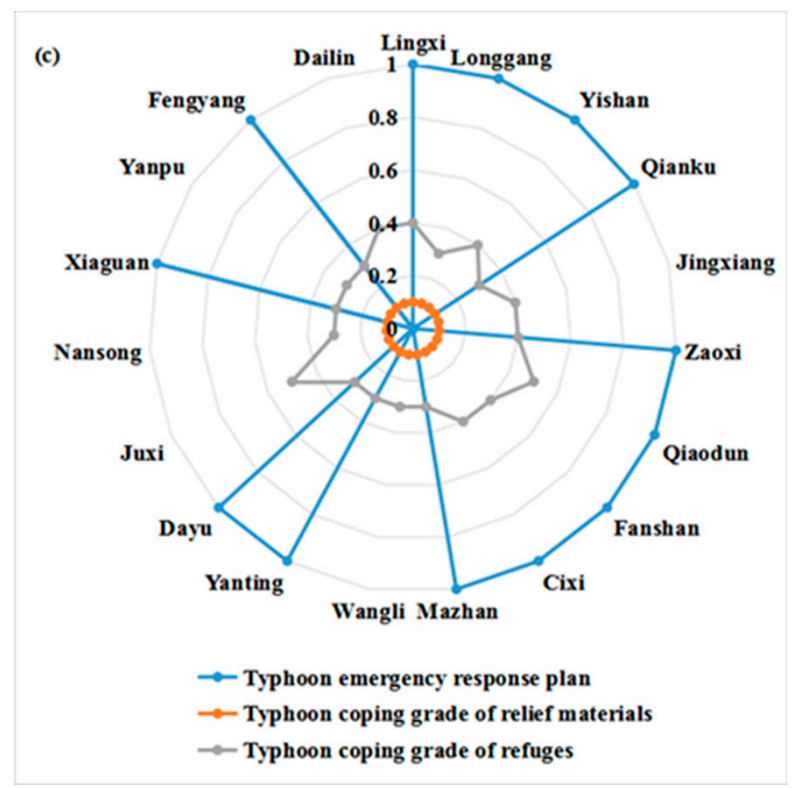

Figure 4. Values of second-grade indices for typhoon reduction ability (a), resilience ability (b), and relief ability (c).

(2) Typhoon resilience ability index

Figure $3 \mathrm{~b}$ shows that the index values of the typhoon resilience ability for all towns were lower than 0.5 . The index values varied significantly due to the differences in the indices of anti-wind grade of house and flood control grade of the facilities (Figure $4 \mathrm{~b}$ ). The highest index values (0.42) of typhoon resilience ability were observed in Lingxi and Longgang, while the lowest $(0.31)$ were found in Wangli and Dayu.

(3) Typhoon relief ability index

The spatial distribution about the index values of typhoon relief ability is displayed in Figure 3c. The lowest value was 0.16 for Wangli, Yanpu, and Nansong, while the highest value was 0.57 for Zaoxi. The variations in index values of typhoon relief ability were mainly caused by differences in typhoon emergency response plans and typhoon coping grade of refuges among towns (Figure 4c).

(4) Typhoon coping capacity grade

The results of the fuzzy comprehensive evaluation model are illustrated in Figure 5. The figure shows that the typhoon coping capacities of the towns were at 12-13 intensity grades. The differences in coping capacity among the towns were influenced by housing insurance, anti-wind grade of the house, flood control grade of the power facilities, and typhoon emergency response plans. Towns with higher economic development levels usually had higher typhoon coping capacities. 


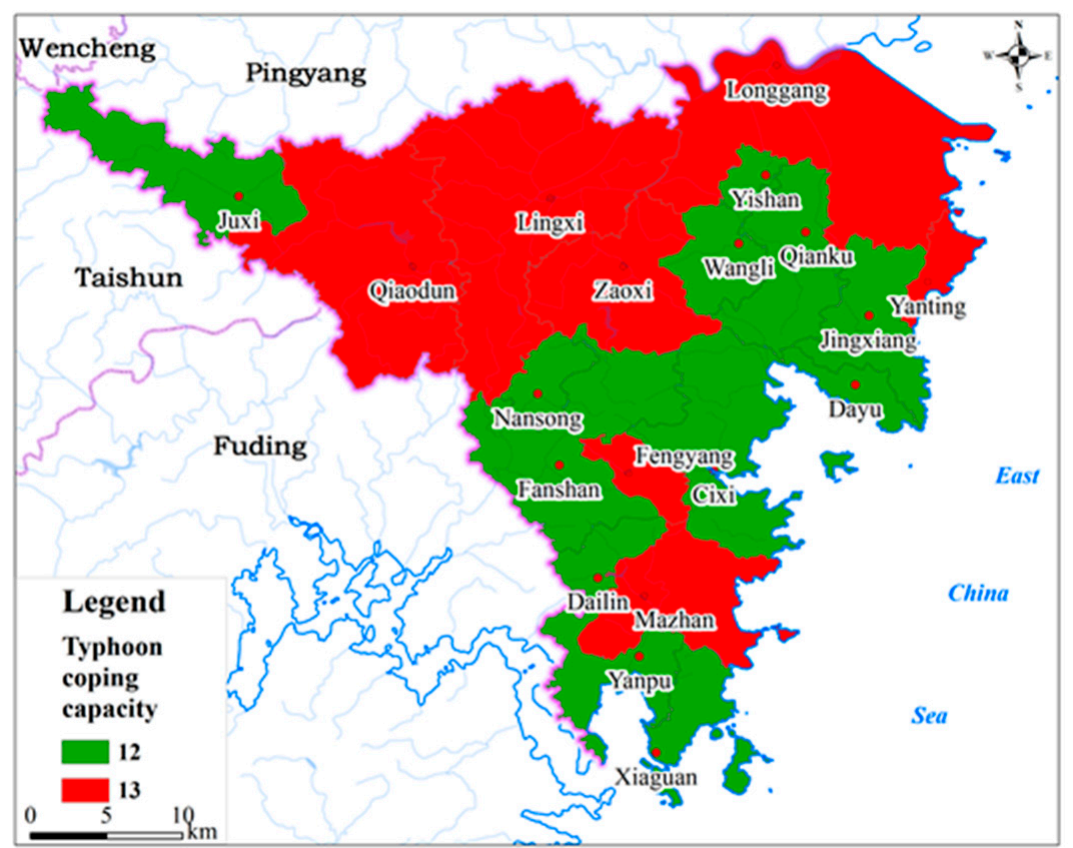

Figure 5. Spatial distribution of typhoon coping capacity in Cangnan County.

\section{Discussion}

Few studies have represented the natural disaster coping capacities as disaster grade based on historical disaster-related data. To understand the earthquake coping capacity in cities, Ferreira et al. (2016) proposed an adaptive earthquake assessment index for cities in Portugal by using a disruption index (DI) [40]. Estember and Abiog (2018) applied the adaptive index to assess the coping capabilities of typhoons, floods, and landslides in the Pangasinan region of Philippines [34]. Tian et al. (2019) identified the spatial distribution of the relative disaster coping capacity for multiple disasters (landslides, rockfall, and debris flow) in the Anning River Basin from the southwest of China [38]. In addition, Kim-Anh et al. (2019) estimated the spatial distribution of typhoon coping capacity in Vietnam by using GIS and other methods [37]. Chen et al. (2020) calculated the value of disaster risk reduction by using expert opinions, questionnaires, and analytic hierarchy process methods [20]. Zhang and Chen (2019) evaluated the value of typhoon and flood disaster coping capacity by analytical hierarchy process and multi-factor analysis through geographic information system (GIS) and the comprehensive weighted evaluation [45]. The assessment results reflected the spatial distribution of natural disaster coping capacity, while they were hardly compared among different regions. Consequently, the results were difficult to use to determine and plan for regional natural disaster coping capacity. In addition, the indices used for the assessment of disaster coping capacity varied widely among the methods. It is necessary to adopt some mathematical methods based on historical data in order to evaluate disaster coping capacity more objectively and accurately.

Therefore, a quantitative conceptual model for the assessment of disaster coping capacity was proposed in this study. It was used to assess the typhoon coping capacity. Based on historical typhoon-related data, information on the relevant equipment, and typhoon prevention-related information on infrastructures, the index data for the assessment of typhoon coping capacity were defined as specific typhoon grade. Typhoon coping capacity was assessed by a fuzzy mathematic model using the indices of typhoon reduction ability, typhoon resilience ability, and typhoon relief ability. The assessment results were characterized as typhoon grade. 
The results of the case study showed that the existing typhoon coping capacities of the towns can deal with 12-13 typhoon intensity grades. The typhoon coping capacity of Mazhan, Longgang, Yanting, Lingxi, and Zaoxi were 13 typhoon intensity grade. The economic development levels of these towns were higher than that of the others. The contributions of reduction ability, resilience ability, and relief ability to typhoon coping capacity significantly varied (Figure 4). Therefore, the indices of resilience ability and relief ability should be improved to enhance the typhoon coping capacity of the towns. The towns with 12 typhoon intensity grade were mainly located in the central, southern, southeastern, and northwestern regions of Cangnan country. These towns have a higher average altitude, complex geographical environment, fragile ecological condition, and less disaster-resistant infrastructure. It is necessary to enhance typhoon coping capacity by increasing the economic investment for disaster reduction. With the development of social economy, the losses from a typhoon might be increased. Residents could increase the level of insurance involvement to reduce adverse consequences of disasters. The results suggested that typhoon coping capacity in the towns from Cangnan can be improved by increasing the investment for insurance, anti-wind grade of house, relief materials, refuges, and emergency response plans.

According to the historic data about typhoon occurrence and the losses in Cangnan, the assessment results were accurate and objective. The index values of typhoon reduction ability, typhoon resilience ability, and typhoon relief ability reflected the advantages and disadvantages of typhoon coping capacity of the towns in Cangnan. The final values successfully reveal the disaster coping capacity dealing with a specific disaster grade. The results of this study indicated that the proposed method was feasible for the quantitative assessment of natural disaster coping capacity.

This study had two main limitations. First, the number of indices used for the assessment of typhoon coping capacity was relatively small due to the unavailability of data. This might induce a bias in the estimation results. The availability of index-related data needs to be improved. However, the relatively limited indices indicated that the method can be applied to quantitively assess the natural disaster coping capacity. Second, the accuracy of index weights needs to be improved.

\section{Conclusions}

The results of the case study indicated that the typhoon coping capacities for the towns of Cangnan County were at 12-13 typhoon intensity grades, which meant that the existing typhoon coping capacities could deal with the typhoon grades. Special attention might be required for the regions with higher vulnerability and hazard impacts while with lower typhoon coping capacity. The typhoon coping capacity in the towns from Cangnan can be improved by increasing the investment for insurance, anti-wind grade of house, relief materials, refuges, and emergency response plans.

The data availability was still a major issue for typhoon coping capacity assessments. However, the indices with available data in this study could reveal the typhoon coping capacity. The results also reflected the advantages and disadvantages of the county's typhoon coping capacity. It also suggested that disaster coping capacity can be assessed by the proposed methods, including comprehensive fuzzy evaluation model and the index system based on historical disaster-related data, as well as information on the relevant equipment and infrastructure for disaster prevention.

Author Contributions: Conceptualization, B.W.; data curation, J.G.; investigation, L.Y.; resources, S.W.; writing—original draft, T.W.; writing—review and editing, B.W. All authors have read and agreed to the published version of the manuscript.

Funding: This research was funded by the National Key Research and Development Program of China (No. 2018YFC1508801).

Acknowledgments: We thank Xu Wei from Beijing Normal University for his valuable advice for this work.

Conflicts of Interest: The authors declare no conflict of interest. 


\section{References}

1. Huang, S.L.; Chang, L.F.; Yeh, C.T. How vulnerable is the landscape when the typhoon comes? An emergy approach. Landsc. Urban Plan. 2011, 100, 415-417. [CrossRef]

2. Lung, T.; Lavalle, C.; Hiederer, R.; Dosio, A.; Bouwer, L.M. A multi-hazard regional level impact assessment for Europe combining indicators of climatic and non-climatic change. Glob. Environ. Chang. 2013, 23, 522-536. [CrossRef]

3. Forzieri, G.; Feyen, L.; Russo, S.; Vousdoukas, M.; Alfieri, L.; Outten, S.; Migliavacca, M.; Bianchi, A.; Rojas, R.; Cid, A. Multi-hazard assessment in Europe under climate change. Clim. Chang. 2016, 137, 105-119. [CrossRef]

4. Mysiak, J.; Torresan, S.; Bosello, F.; Mistry, M.; Amadio, M.; Marzi, S.; Furlan, E.; Sperotto, A. Climate risk index for Italy. Philos. Trans. Royal Soc. A 2018, 376, 20170305. [CrossRef] [PubMed]

5. Ruiter, M.C.; Couasnon, A.; van den Homberg, M.J.C.; Daniell, J.E.; Gill, J.C.; Ward, P.J. Why we can no longer ignore consecutive disasters. Earths Future 2020, 8, e2019EF001425. [CrossRef]

6. EM-DAT. UNISDR and CRED Report: Economic Losses, Poverty \& Disasters (1998-2017). 2018. Available online: https://www.unisdr.org/files/61119_credeconomiclosses.pdf (accessed on 20 March 2020).

7. Zhou, Y.; Liu, Y.; Wu, W.; Li, N. Integrated risk assessment of multi-hazards in China. Nat. Hazards 2015, 78, 257-280. [CrossRef]

8. Wang, L. The Assessment of Typhoon Disaster and the Development and Implementation of Its Disaster Reduction Decision Support Sysytem; Nanjing University of Information Science \& Technology: Nanjing, China, 2016. (In Chinese)

9. Ministry of Emergency Management of the People's Republic of China. The Ministry of Emergency Management Released the Basic Information on Natural Disasters in China in 2019. Available online: https://www.mem.gov.cn/gk/tjsj/ (accessed on 20 March 2020).

10. Keogh, D.U.; Apan, A.; Mushtaq, S.; King, D.; Thomas, M. Resilience, vulnerability and adaptive capacity of an inland rural town prone to flooding: A climate change adaptation case study of Charleville, Queensland, Australia. Nat. Hazards 2011, 59, 699-723. [CrossRef]

11. Hu, J.F.; Yang, P.G.; Lv, A.F.; Zhang, B.J.; Li, L. Regional comprehensive evaluation index system of disaster reduction capacity based on ISM. J. Catastrophology 2014, 29, 75-80. (In Chinese)

12. Ji, H.; Lee, D. Disaster risk reduction, community resilience, and policy effectiveness: The case of the Hazard Mitigation Grant Program in the United States. Disaster 2019. [CrossRef]

13. Chakraborty, A.; Joshi, P.K. Mapping disaster vulnerability in India using analytical hierarchy process. Geomat. Nat. Hazards Risk 2016, 7, 308-325. [CrossRef]

14. Weis, S.W.M.; Agostini, V.N.; Roth, L.M.; Gilmer, B.; Schill, S.R.; Knowles, J.E.; Blyther, R. Assessing vulnerability: An integrated approach for mapping adaptive capacity, sensitivity, and exposure. Clim. Chang. 2016, 136, 615-629. [CrossRef]

15. Shen, G.; Hwang, S.N. Spatial-Temporal snapshots of global natural disaster impacts revealed from EM-DAT for 1900-2015. Geomat. Nat. Hazards Risk 2019, 10, 912-934. [CrossRef]

16. UNISDR (United Nations International Strategy for Disaster Reduction). UNISDR Terminology on Disaster Risk Reduction; UNISDR: Geneva, Switzerland, 2017; Available online: https://www.unisdr.org/files/52828_ nationaldisasterriskassessmentpart52821.pdf (accessed on 19 March 2020).

17. IDNDR (International Decade for Natural Disaster Reduction). Yokohama Strategy and Plan of Action for a Safer World: Guidelines for Natural Disaster Prevention, Preparedness and Mitigation. 1994. Available online: https://www.unisdr.org/we/inform/publications/8241 (accessed on 4 March 2020).

18. Maly, E.; Suppasri, A. The Sendai framework for disaster risk reduction at five: Lessons from the 2011 great east Japan earthquake and Tsunami. Int. J. Disaster Risk Sci. 2020, 11, 167-178. [CrossRef]

19. FEMA (Federal Emergency Management Agency). State Capability Assessment for Readiness. 2009. Available online: https://www.docin.com/p-238379278.html (accessed on 12 March 2020).

20. Chen, F.; Jia, H.; Zhang, C. A comprehensive method for evaluating marine disaster risk reduction capacity in China. Sustainability 2020, 12, 825. [CrossRef]

21. DTRS (Department of Transport \& Regional Services). Natural Disaster in Australia: Reforming Mitigation, Relief \& Recovery Arrangements-A Report to the Council of Australian Governments by a High Level Official's Group (2002-2008); Department of Transport \& Regional Services: Canberra, Australia, 2004. 
22. Zeng, L.F. Risk evaluation of typhoon disasters in the coastal areas in Guangxi. J. Catastrophol. 1996, 11, 43-47. (In Chinese)

23. Xie, L.L. A method for evaluating cities' ability of reducing earthquake disasters. Earthq. Eng. Eng. Dyn. 2006, 26, 1-10. (In Chinese)

24. Gao, Z.C.; Yu, M.; Ding, Z.D. Typhoon storm surge risk assessment based on GIS-A case study of Taizhou. Marine Environ. Sci. 2012, 31, 439-442, 447. (In Chinese)

25. Kappes, M.S.; Keiler, M.; von Elverfeldt, K.; Glade, T. Challenges of analyzing multi-hazard risk: A review. Nat. Hazards 2012, 64, 1925-1958. [CrossRef]

26. Daramola, A.Y.; Oni, O.T.; Ogundele, O.; Adesanya, A. Adaptive capacity and coping response strategies to natural disasters: A study in Nigeria. Int. J. Disaster Risk Reduct. 2016, 15, 132-147. [CrossRef]

27. Parsons, M.; Glavac, S.; Hastings, P.; Marshall, G.; McGregor, J.; McNeill, J.; Morley, P.; Reeve, I.; Stayner, R. Top-down assessment of disaster: A conceptual framework using coping and adaptive capacities. Int. J. Disaster Risk Reduct. 2016, 19, 1-11. [CrossRef]

28. Shi, Y.; Zhai, G.; Zhou, S.; Lu, Y.; Chen, W.; Liu, H. How can cities adapt to a multi-disaster environment? Empirical research in Guangzhou (China). Int. J. Environ. Res. Public Health 2018, 15, 2453. [CrossRef] [PubMed]

29. Cutter, S.L.; Boruff, B.J.; Shirley, W.L. Social vulnerability to environmental hazards. Soc. Sci. Quart. 2003, 84, 242-261. [CrossRef]

30. Li, L.; Shen, Q. The evaluation of storm surge prevention and mitigation capability: Case of coastal cities in Shandong Province. China Fish. Econ. 2011, 29, 98-106. (In Chinese)

31. Li, J. Risk Assessment of Maize Drought Disaster in Guizhou Province; North China University of Water Resources and Electric Power: Zhengzhou, China, 2016. (In Chinese)

32. Cao, L.D.; Li, J.L.; Xu, Q.H.; Yuan, L.X.; Wang, M.Y.; Huang, D.P. Capacity of flood disaster prevention and reduction of Ningbo City: Primary assessment. J. Ningbo Univ. 2014, 27, 84-90. (In Chinese)

33. Hajibabaee, M.; Amini-Hosseini, K.; Ghayamghamian, M.R. Earthquake risk assessment in urban fabrics based on physical, socioeconomic and response capacity parameters (a case study: Tehran city). Nat. Hazards 2014, 74, 2229-2250. [CrossRef]

34. Estember, R.D.; Abiog, M.C.M. Vulnerability assessment of Pangasinan Province to typhoons, floods and landslides. In Proceedings of the 4th Electronic and Green Materials International Conference, Bandung, Indonesia, 27-28 July 2018. AIP Conference Proceedings.

35. Hu, J.F.; Yang, P.G.; Yang, Y.Q.; Wu, J.J. Study on evaluation index system and method for flood control and disaster reduction capacity. J. Nat. Disasters 2010, 19, 82-87. (In Chinese)

36. Jiang, W.G.; Deng, Y.; Tang, Z.H.; Cao, R.; Chen, Z.; Jia, K. Adaptive capacity of mountainous rural communities under restructuring to geological disasters: The case of Yunnan Province. J. Rural Stud. 2016, 47, 622-629. [CrossRef]

37. Kim-Anh, N.; Liou, Y.A.; Terry, J.P. Vulnerability of Vietnam to typhoons: A spatial assessment based on hazards, exposure and adaptive capacity. Sci. Total Environ. 2019, 682, 31-46.

38. Tian, C.S.; Fang, Y.P.; Yang, L.E.; Zhang, C.J. Spatial-temporal analysis of community resilience to multi-hazards in the Anning River basin, Southwest China. Int. J. Disaster Risk Reduct. 2019, 39, 101144. [CrossRef]

39. Huang, X.; Song, J.; Li, X.; Bai, H. Evaluation model of synergy degree for disaster prevention and reduction in coastal cities. Nat. Hazards 2020, 100, 933-953. [CrossRef]

40. Ferreira, M.A.; de Sa, F.M.; Oliveira, C.S. The Disruption Index (DI) as a tool to measure disaster mitigation strategies. Bull. Earthq. Eng. 2016, 14, 1957-1977. [CrossRef]

41. Sun, D.C.; Huang, J.; Wang, H.M.; Wang, Z.Q.; Wang, W.Q. Risk assessment of urban flood disaster in Jingdezhen City based on analytic hierarchy process and geographic information system. 3rd International Conference on Water Resource and Environment, Qingdao, China. IOP Conf. Ser. Earth Environ. Sci. 2017, 82, 012075. [CrossRef]

42. Wang, J.J.; He, Y.B.; Yang, L.; Chen, Y. Comprehensive multi-hazard risk assessment of villages and towns in mountain areas based on GIS. Chin. J. Geol. Hazard Control 2018, 29, 102-112. (In Chinese)

43. Jha, R.K.; Gundimeda, H. An integrated assessment of vulnerability to floods using composite index-A district level analysis for Bihar, India. Int. J. Disaster Risk Reduct. 2019, 35, 101074. [CrossRef] 
44. Zhang, Y.C.; Wang, L.; Xiong, X.; Shi, L.H. Evaluation of typhoon disaster prevention and mitigation ability in Fujian province based on set pair analysis. J. Catastrophol. 2015, 30, 85-88. (In Chinese)

45. Zhang, H. A study on GIS-Based Risk Assessment and Management Measures of Flood/Waterlogging Disasters in Middle and Lower Reaches of Liao River of the Northeast China; Northeast Normal University: Changchun, China, 2007. (In Chinese)

(c) (

(C) 2020 by the authors. Licensee MDPI, Basel, Switzerland. This article is an open access article distributed under the terms and conditions of the Creative Commons Attribution (CC BY) license (http://creativecommons.org/licenses/by/4.0/). 